Policy Research Working Paper 1228

\section{Competition, Competition Policy, and the GATT}

Bernard M. Hoekman

Petros C. Mauroidis
Further moves to liberalize

trade and to implement existing GATT rules and principles may have a greater impect on global competition than would the pursuit of harmonization of competition policy.

The World Bank

Europe and Central Asia, and Middle East and North Africa Regions Technical Department Finance and Private Sector Development Division December 1993 
Policy Research Working Paper 12.28

\section{Summary findings}

Hoekman and Mavroidis argue that further moves $\mathrm{t} n$ liberalize trade and to implement existing GATT rules and princ ples may have a greater impact on global competition than would the pursuit of harmonization of competition policy.

They also suggest that current GATT rules and cas? law provide scope for disputes to be brought before the GATT that relate to toth the application and the nonapplication of existing domestic competition laws of GATT contracting parties. This leads to de facto

discriminatic $n$ between domestic and foreign products.

Little use has been made of the GATT in this connection. Perhaps existing indirc $t \tau$ avenues for raising competition-related disputes in the GATT should be pursued more actively. This would help identify what specific government policies might be the subject of multilateral negotiations and explicitly incorporated into the GATT framework.

This paper is a product of the Finance and Private Sector Development Division, Europe and Central Asia, and Middle East and North Africa Regions Technical Department. Copies of the paper are available free from the World Bank, $1818 \mathrm{HStreet}$ NW, Washington, DC 20433. Please contact Laura O'Connor, room H8-090, extension 37009 (34 pages). December 1993.

The Policy Research Working Paper Series disseminates the findings of work in progress to encourage the exchange of idans about development issues. An objective of the series is to get the fir. Lings out quickly, even if the presentations ane less than fully polished. The papers camy the names of the authors and should be used and cized accordingly. The finding inerpretations, and conclusions are the authors' oun and should not be attributed to the World Bank, its Executive Boand of Diructorn, or any of its member countries. 


\title{
Competition, Competition Policy and the GATT ${ }^{*}$
}

\author{
Bernard M. Hoekman \\ The World Bank \\ ECA/MENA Technical Department \\ Washington D.C.
}

\author{
Petros C. Mavroidis \\ GATT Secretariat \\ Legal Division \\ Geneva
}

- We are grateful to Sincad Deevy and Anne Vittori for excellent secretarial assistance, and to Laurence Boisson de Chazournes, Clemens Boonekamp, Mark Koulen, Aaditya Matoo, Emst-Ulrich Petersmann, Frieder Roessler, Richard Snape and David Trainor for helpful discussions and suggestions. Any remaining errors and shortcomings of the paper are, of course, our own. The views expressed in this paper are personal and should not be attributed to the World Bank or the GATT Secretariat. 


\section{Introduction}

Competition policy is frequently mentioned as an issue area that should be on the agenda of the next round of multilateral trade negotiations. Whether or not the Uruguay round is concluded successfully, competition policy-related matters are likely to confront policymakers increasing!y often in the immediate future. Sir Leon Brittan is perhaps best krown among those who have called for multilateral disciplines in the area of competition policy, proposing that:

The next GATT Round should include restrictive business practices and cartels on its agenda. The aim should be to draw up common rules, lay down the principle that restrictive arrangements are not enforceable at law and that governments are responsible internationally for the implementation of these rules and procedures ... For mergers, common rules should also be established, as well as a common commitment to enforce them $(1992$, p. 108, emphasis added). ${ }^{1}$

The rationales that have been suggester for addressing competition policy in the GATT context include: (1) inadequate enforcement or nonexistence of national antitrust rules for traded goods and/or for nontraded sectors such as distribution may distort trade flows; (2) enforcement of national competition laws may distort trade, e.g., an antitrust exemption for export cartels; (3) conglomerates with substantial market power at the global level are beyond the reach of national antitrust jurisdictions; and (4) antidumping policies are inconsistent with the criteria employed under domestic competition rules. ${ }^{2}$

Some of these dimensions are closely linked. For example, an advocate of antidumping policies might argue it is a justifiable attempt by importing country governments to offset the market access restrictions existing in an exporting firm's home country that underlie the ability of such firms to dump. Such restrictions may consist of import barriers preventing arbitrage, but may also reflect the non-existence or non-enforcement of competition law by the exporting

\footnotetext{
I Se also Jacquemin (1993), who has supported Brittan's suggestion. See Bhagwati (1993), Meessen (1989) and Trachtman (1993) for evaluations of the need for -- or welfare effects -- of harmonization of competition and related policies as opposed to coordination/cooperation, and Davidow (1981) for a discussion of past history.

${ }^{2}$ See, e.g., Ostry (1990), Feketekuty (1992), and Boner and Krueger (1991).
} 
country. ${ }^{3}$ Antidumping can then be defended as a second-best instrument to offset such 'government-made' cumpetitive differences, the first-best solution being held to be the adoption of common competition policies. Conversely, those who emphasize the protectionist nature of antidumping policy invariably point out the inconsistency of the underlying rules and prinuiples with those of domestic competition laws. While the conclusien drawn is also that antidumping should be replaced with procedures that are consistent with competition legislation, the second-best rationale for the status quo is rejected."

In Section II the question is asked whether the pursuit of inter-governmental cooperation on competition policy is the best way of increasing competition and should therefore be given priority. ${ }^{5}$ Competition or antitrust rules are simply one type of policy that affect the contestability of markets. Other policies may have a more direct impact on competition. Trade barriers in particular - including voluntary export restraint (VER) agreements and antidumping actiuns - are perhaps the primary means of restricting the contestability of a market, and are often complemented Ly nonborder measures such as subsidies, discriminatory procurement practices, or differences in standards. A number of these non-border measures have been subjected to multila $4: 31 l y$ agreed disciplines, but these can be strengthened substantially. Will focusing on competition policy be more productive in terms of enhancing the contestability of markets than focusing on other government policies that more directly restrict market access or distort competition? Clearly an exclusive focus on competition policy is not optimal, nor is this proposed by anyone. The issue is to determine the relative weight that should be given to this policy area, and the approach that could be followed. We argue that efforts might more productively center on ensuring that current GATT (or post-Uruguay Round) rules and principles enhancing competition are actually applied by contracting parties, and on further attempts to eliminate the 'loopholes' in the GATT allowing

\footnotetext{
${ }^{3}$ Thus, the U.S. has claimed that lax Japanese antitrust enforcement permits Japanese firms to collude, raise prices, and use part of the resulting rents to cross-subsidize (dump) products sold on foreign markets (Trachtman, 1993, p. 54).

4 E.g., Barcelo (1979), Caine (1981), Messerlin (1990).

${ }^{5}$ In this paper competition policy is defined as the set of rules and disciplines maintained by governments relating to the exercise of market power and the abuse of a dominant position by enterprises. The underlying objective tends to be efficient resource allocation, and therefore the maximization of national welfare. Competition is used as a synonym for contestability of markets.
} 
contracting parties to impose trade restrictions. Of course, political considerations may prohibit this. But, if so, serious doubts can be expressed regarding the impact on competition of the outcome of discussions in the GATT on the coordinated application or harmonization of competition policy.

Section III investigates the reach of current GATT rules and disciplines with respect to business practices restricting the contestability of markets, and explores the extent to which a 'minimalistic' approach might be pursued in this area. Jackson (1992) has suggested a number of possible ways to approach competition policy-related issues from a GATT perspective, one of which is to develop an interpretation of GATT in this respect. This part of the paper can be seen as an attempt to pursue this suggestion. It involves an exploration of the scope to bring 'violation cases' (alleging that a government action is inconsistent with a GA.TT rule) and 'nonviolation cases' (claiming that implementation of GATT-con:sstent measures have nonetheless nuliified or impaired prior negotiated conditions of market access). The wording and interpretation of current GATT rules are such that many competition policy-related issues ${ }^{6}$ can be raised if government support of such practices leads to de facto discrimination between domestic and fore: products. A key issue in this regard is the definition of 'support'. A case is made that passive support, e.g., exemptions from - or nonenforcement of - antitrust already may be sufficient to bring complaints before GATT.

Section IV provides a summary of which competition-distorting practices can be addressed under thic existing GATT, identifies a number of the more important practices that currently cannot be addressed in the GATT forum, and discusses the desirability and some the implications of expanding multilateral disciplines to the latter. Section $\mathrm{V}$ concludes.

\section{GATT as an Instrument to Increase Competition Through Market Access}

Although the GATT negotiating agenda has expander over time, the focus has always been on market access through a reduction in trade barriers and the abolition of discrimination among products, be it through border measures or 'domestic' policies. By reducing trade barriers the costs for foreign producers to contest markets decline. Similarly, the obligation to bind tariffs

\footnotetext{
- In what follows competition policy-related disputes are defined as disputes relating to either the non existence or non enforcement of competition policy, or to the enforcement of such policies. An antitust exemption is an example of enforcement that might give rise to a dispute.
} 
can provide exporters with greater certainty regarding market access conditions, as GATT rules allow contracting parties to contest measures employed by another contracting party that nullify or impair such bindings. Trade liberalization is a fundamental component of any policy that seeks to ensure that markets are competitive (Blackhurst, 1991). In ti.eory, of courso, free trade is neither necessary nor sufficient to ensure competitive outcomes. It is not necessary because in principle other policies - i.e., competition policy - can be used to achieve the same outcome. But in such cases competition policy will to a large extent be compensating for the anti-competitive effects induced by the trade barriers that are maintained. Abolition of the trade barriers would be a much more effective and lower cost method of fostering competitive outcomes. Free trade may not be sufficient if foreign firms hive global market power, foreign suppliers collude with each other and/or with domestic producers, or if relevant markets are local (i.e, products are nontradable) and there are restrictions on inward foreign direct investment. Domestic competition laws will generally be required to complement free trade in order to ensure competitive conduct. ${ }^{7}$

While free trade may not be sufficient to guarantee competitive conduct on individual markets, it is an efficient means of fostering competition. One of the fundamental r jectives underlying the GATT can therefore be argued to be competition, even though the Preamble to the GATT does not explicitly mention competition as a goal. Not only do GATT rules and procedures foster competition on product markets, but they also promote competiticn between regulatory regimes. The General Agreement applies to trade policies and policies having an impact on international trade flows. It seeks to establish the competitive conditions on the basis of which firms from contracting parties compete in world trade. Endowments and those aspects of member country regulatory regimes that are not subjected to agreed disciplines are taken as given, the implicit premise being that nations compete on the basis of these.

Two ideal types or 'models' for reciprocal liberalization of market access can be distinguished. The first can be called 'free market access' and is premised on the maintenance of national sovereignty regarding non-border policies. In such a world there is free trade and frectom to engage in foreign direct investment. Countries remain sovereign, but do not pursue

\footnotetext{
1 See Boner and Krueger (1991). This is also the case if not only trade, but also inward direct investment is unconstrained. Concerns relating to foreign collusion are generally overstated, as are the difficulties of maintaining the stability of cartels and the reach of naional antitrust laws.
} 
any discriminatory regulation of foreign products or producers, and compete on the basis of their natural endowments and regulatory regimes. Given the sovereignty constraint, some economists have argued that this is the optimal institutional structure (Corden, 1987; Siape, 1987). The second model is one whe.a governments seek to further integrate their economies and are willing to cooperate on various domestic regulatory policies. In practice the first model can be only observed - albeit often imperfectly - in federal states, whereas the EC is an (also imperfect) example of the second model. In the literature the approaches underlying these two models are sometimes described by the terms negative and positive integration, the first implying that governments agree not to do certain things, the second that they agree to do certain things. ${ }^{8}$

Economic integration is not the objective of GATT, nor is 'free market access'. However, conceptually it is much closer to the first than to the second model, as negative integration predominates. The most binding disciplines that are imposed pertain to measures taken or enforced at a country's border. With respect to other regulations and policies contracting parties largely retain their sovereignty. The approach taken towards non-border policies is simply to seek agreement to reduce or eliminate discrimination, and to establish procedures und $\rightarrow r$ which parties may seek compensation for actions of other governments that nullify or impair existing market access conditions. The GATT approach has been quite successful in greatly reducing tariffs, and has allowed contracting parties to make steady progress on reducing the discriminatory impact of other policies. The key element is usually agreement not to use certain measures or to follow specific procedures when implementing various policies.

But, disciplines in many areas remain quite limited. Governments continue to have a great deal of latitude to impose trade restrictions or $F^{\prime}$. sue other policies that reduce the contestability of domestic markets. Notwithstanding the progress that has been achieved thus far in the Uruguay Round, implementation of the existing draft agreements would not come close to ensuring free trade, let alone free market access. ${ }^{9}$ In large part this is because contingent protection remains relatively readily accessible to import-competing firms. Although procedural changes in the AntiDumping Code reduce discretion with respect to methodologies used to determine dumping and

\footnotetext{
See Hoekman (1993) for further discussion and references to the literature.

${ }^{9}$ See GATT (1992) for a summary of ali the draft agreements.
} 
injury margins, many of the opportunities provided by existing rules for adopting procedures with a protectionist bias remain untouched. The proposed revisions to the rules do not mandate that economy-wide implications (including consumer interests or domestic competition aspects) be taken into account in investigations. Antidumping is likely to remain an oft invoked escape clause. The draft Uruguay Round agreement on safeguards (Article XIX) will do little to induce firms to shift away from using antia, ruping, even though it goes some way towards incorporating the status quo into the GATT. The draft agreement requires all existing voluntary export restraint agreements (VERs) to be notified and abolished or converted into GATT-consistent ineasures within 4 years. ${ }^{10}$ It allows for selectivity if imports from some countries are shown to have increased "disproportionately" in relation to the total increase in imports of the product concerned, allows for quotas to be imposed, provides the option tiat quotas be administered by exporters, and eliminates compensation for affected exporting countries for three years. The revisions to Article XIX therefore basically imply that VER-type actions would become feasible under GATT auspices, albeit subject to time limits (maximum du.ation of 8 years) and degressivity. Greater use can therefore be expected of GATT's general safeguard mechanism. While not necessarily reducing the use of $\mathrm{QRs}$ or antidumping actions, the agreement would lead to greater transparency of trade policies.

It is important to recall the paradoxes that characterize antidumping. Article VI of the GATT - which is the only GATT provision to deal with governmenta! measures (antidumping) intended to offset perceived private anticompetitive behaviour (dumping) - is the GATT Article most directly related to competition policy concerns. Although fo-mally taken by governments, antidumping investigations are initiated by private entities and can therefore be seen as a GATTlegal means for private parties to seek the implementation of government-enforced restrictions on competition. It is well docunıented that antidumping may facilitate (tacit) collusion between import-competing firms in the administering country, between comptitors located in the different countries producing similar goods, and the possible cascading of protection along the production

\footnotetext{
10 Contracting parties may each keep one measure in effect until the end of 1999.
} 
stream within a particular country." Antidumping, far from being a pro-competitive practice, is an anti-competitive one. Empirical studies have demonstrated that antidumping actions have a significant impact in terms of reducing competition in affected markets. Thus, antidumping tends to promote the result it is suppused to combat: less rather than more compatitive pricing. ${ }^{12}$

While antidumping is a major loophole in the GATT in reducing the contestability of markets, $i t$ is by no means the only one. Other policy areas where attention col' 1 fruitf 1 lly focus include negotiating further disciplines on agricultural support policies, governme:at procurement, subsidies, policies restricting access in service markets, and strengthening disfute settlement and enforcement procedures. Moreover, there may be a need to expand disciplines to cover policies affecting foreign direct investment, an area that will remain substantially outside the scope of the post-Uruguay Round trading system. Space considerations prohibit a discussion of all these issues. The question of interest here is where the negotiation of competition policy disciplines should rank in comparison to these other issues. This can only be ancwered subjectively. We believe it should not rank very highly, especially given the potential reach of existing GATT disciplines and procedures (see Section III) and the magnitude of other 'holes' in the GATT, unless an explicit link is made with the abolition of antidumping provisions.

Experience demonstrates that multilateral agreement on the :-doption of common competition policies and abolition of antidumping is difficult to achieve. Where it has proven possible, it cccurred in a bilateral or regional setting. The two regional arrangements where cooperation on antitrust proved possible - the EC/European Economic Area and the Closer Economic Relations (CER) Agreement between Australia and New Zealand - entail far-reaching liberalization of trade in goods, services and factors of production, as well as govemment procurement and state aids (sliusidies). The NAFTA, in contrast, does not contain disciplines on subsidies that go beyond those of the GATT, does not imply common antitrust rules or enforcement, and continues to allow

\footnotetext{
"See Hoekman and Leidy (1992) for a discussion of cascading. The Tokyo Round antidumping code explicitly requires that in determining whether dumped imports are causing material injury the existence of restrictive business practices be taken into account. If injury is due to a restrictive practice pursued by the domestic industry, any resulting 'self-inflicted' injury is not to be attributed to dumped imports (Agreement on the Implementation of Article VI of the General Agreement on Tariffs and Trade, Art.3:4). However, this provision has had little effect in practice (Mescerlin, 1990b).

${ }^{12}$ See, e.g., Finger (1993), Messerlin (1989, 1990a), Stern (1993) and Tharakan (1991).
} 
for antidumping. The regional experience suggests that harmonization of antitrust and abolition of antidumping not only requires concurrent, if not prior, agreement to eliminate trade and investment restrictions ('free maarket access'), but also the adoption of common disciplines on the use of state aids.

In contrast to seeking furthar liberalization of trade/FDI, the pursuit of multilateral competition rules involves soordinating/iarmonizin regulations. This in turn opens up the possibility that the proress is captured by sperific industry or government interests, ${ }^{13}$ and/or allows Evvernments that are more interested in regulating than freeing international trade/comperition to seek to attain their ubjectives in a less than transparent manner. The probability of regulatory capture is non-negligible, as demonstrated the apparent intent of the EC Commission to allo Japanese car producers to enforce negotiated market share 'forecasts' through a relaxation of EC. competition disciplines (Matoo and Mavroidis, 1993). The mere fact that some of the governments seeking multilateral disciflines on business fractices apparently are not prepared to invoke provisions of GATT that could, in principle, curb some of these practices, suggests that competition may well be the liser. More generally, existing antitrust rules and procedures differ widely across jurisdictions. In part this reflects different concerns with and approaches to the regulatory capture problem. Such differences are likely to prove to be an additional obstacle to reaching multilateral agreement on competition policies.

It is also important to keep in mind that the political economy of cooperation on compecition policies is likely to be different from more traditional trade liberalization. GATT negotiating rounds have been motivate $y$ public choice rationales: they allowed liberalization to occur by inducing export-oriented industries, firms desiring to have access to lower cost, foreign-produced intermediates, and consumer groups to offset the political power of protected import competing interest groups. The bindir. , onstraint on liberalization was more political than economic: few countries maintained 'optimal' tariffs. But the economic cost of coordinated application or harmonization of competition policy may be non-negligible. For example, the exertion of monopsony power by importing firms in a country over exporters may benefit the country as a whole. Exporters may want to see antitrust rules enforced on such monopsonists, but this will

${ }^{13}$ See Neven et al. (1993) for a review of the literature on regulatory capture in the antitrust context. 
not be in the interest of the government concerned. Incentives may be similarly skewed with respect to the exercise of market power by firms on export markets. Assuming appropriate competition policies are enforced regarding the behavior of these firms in their home market, the incentives for the exporters' government to regulate behavior on export markets is low, as suck: behavior can be argued to be in the nation's interest. It is then unclear where the internal political pressure or support for preventing the exercise of market power on foreign markets will come from. Of course, a case can be made that there wi be global efficiency gains from such an extension of antitrust, and that each country will share in such gains as long as enough governments cooperate (Caves, 1987). The problem with this from a practical perspective is that the distribution ant magnitude of such gains are uncertain and accrue to consumers. These have little influence in domestic political markets of exporting countries. It is no accidert hat the regulation of behavior by firms on export markets and policies by guvernments affecting exports (e.g., export taxes) are not addressed by GATT. ${ }^{14}$ Importing countries that face firms with market power are likely to better off by ensuring that their markets are truly open - thus confronting export monopolies or cartels with competition, or the threat thereof - and by applying national antitrust to the extent possible.

The foregoing arguments imply that negctiations must first center on attaining the necessary conditions - free or at least substantially freer market access - before pursuit of harmonization of antitrust becomes a realistic proposition. Even seeking 'only' the coordinated application of competition rules presupposes agreement on common objectives. This has been and continues to be lacking in tie. GATT context, which is why international cooperation on commercial policies has been mostly limited to 'negative integration' - i.e., agreement not to pursue specific policies. Realistically the most that can be expected in the multilateral context are further moves towards satisfying the necessary conditions, i.e., attaining the first 'ideal' model described earlier, perhaps with GATT's enforcement/dispute settlement mechanism extended to include certain competition policy-related disputes. The degree to which such extension is required may be rather minor. As discussed at length in the next Section, GATT already provides substantial scope to raise such

\footnotetext{
${ }^{14}$ See Auquier and Caves (1979) for a discussion of the exemption from competition policy of 'rent extracting' behavior by home country firms on export markets, as well as the optimal policy that should be pursued by the home country.
} 
disputes.

\section{Applying the GATT to Competition Policy-related Disputes}

GATT deals only with government policies. Anti-competitive practices pursued by private entities are therefore not subiect to GATT. While this is no doubt one of the rationales underlying calls for GATT to address competition policy, in many instances anti-competitive business practices of firms will need both government approval (e.g., an antitrust exemption) and government support (e.g., trade barriers). If a contracting party supports business practices that lead to de facto if not de jure discrimination against foreign products GATT dispute settlement procedures may be invoked. Measures that are inconsistent with Article III (National Treatment) or with complementary rules on state-trading enterprises and quantitative restrictions (Articles XVII and XI), may give rise to a 'violation' complaint (under Art. XXIII:1(a)). Measures that are not inconsistent with the General Agreement, but nullify or impair an existing concession may give rise to a so-called 'non-violation' complaint (under Art. XXIII:1(b)). It should be noted at the outset that much of what follows is not specific to competition policy legislation, this simply being one type of instrument that may violate GATT obligations.

\section{Article III: National Treatment on Internal Taxation and Regulation}

Article III is one of the key provisions in the General Agreement, requiring that Government's guarantee that domestic and imported products are treated equally, apart from whatever forms of discrimination against fore: $g n$ like products are allowed by other GATT Articles (e.g., a tariff). Equal treatment is not necessarily guaranteed through the application of identical legal provisions, as this might lead to de facto discrimination in favour of domestic products. Panels have interpreted $\mathrm{Ar}$. III as an obligation of result: contracting parties have discretion how to implement Art.III. But whatever means are chosen must result in treatment of imported products no less favourable than that accorded domestic ones. ${ }^{\text {Is }}$ As Art.III purports to guarantee the equality of competitive conditions, GATT Panels have pronounced that trade effects are totally

\footnotetext{
${ }^{15}$ It is upon the contracting party applying differential treatment to show that, in spite of such differences, the no less favourable treatment standard of Art.III is met. 'US-Section 337' Panel Report, GATT Basic Instruments and Selected Documents (hereafter BISD) 36S/387, \$5.11.
} 
irrelevant in this context. ${ }^{16}$ Moreover, Art.III applies irrespective of whether a specific tariff commitment has been undertaken by the importing contracting party, ${ }^{17}$ therefore applies to all imports, and does so on a product-by-product basis. ${ }^{18}$ Although not spelled out explicitly, it goes without saying that national treatment can be guaranteed only in the territory of the importing contracting party. Equally obvious, if there is no domestic production, Article III does not apply. ${ }^{19}$ Finally, the mere existence of mandatory legislation may violate Art.III, as may the mere exposure to the risk that national treatment will not be guaranteed has been judged as GATT-inconsistent. ${ }^{20}$ Art.III distinguishes between policies involving charges (fees and taxes) and 'non-charge' policies. Art.III:2 pertains to internal taxes or other charges applied directly or indirectly to like domestic products, whereas Art.III:4 speaks of all laws, regulations and requirements affecting the internal sale, offering for sale, purchase, transportation, distribution or use of like domestic products. The term 'like products' denotes directly competitive or substitutable products. See the Interpretive Note to Art.III. To the extent that domestic antitrus* laws affect the internal sale, offering for sale, purchase, transportation, distribution or use of products, they can be considered

\footnotetext{
${ }^{16}$ Thus, a recent Panel Report stated that: "Art.III:2 protects competitive conditions between imported and domestic products but does not protect expectations on export volume ... is not conditional on a 'trade effects test' nor is it qualified by a minimum standard," 'US- Measures Affecting Alcoholic and Malt Beverages' DS32/R, adopted 19 June 1992, \$5.6. The same Panel Report subsequently makes a similar argument with respect to Art.III:4. This conclusion with respect to Art.III: 2 was already reached in 'Brazilian Internal Taxes' GATT/CP.3/42, adopted on 30 June 1949, Vol.II/185, \$16.

${ }^{17}$ See GATT Doc. GATT/SP.3/42, adopted on 30 June 1949, II/181-4.

${ }^{18}$ Arguments that Art.III only require that on average imported and domestic products be treated in the same way have been rejected on the basis that this would lead to great uncertainty about the conditions of competition between imported and domestic products and thus defeat the purposes of Art.III. See Panel Report on "US-Section 337 of the Tariff Act of 1930", L/6439, adopted on 7 November 1989, BISD 36S/387, \$5.14.

${ }^{19}$ See Panel Report on "Canada-Administration of the Foreign Investment Review Act (FIRA)", L/5504, adopted on 25 June 1983, BISD 30S/159, \$\$5.9-5.11.

${ }^{20}$ On the first, see 'US-Taxes on Petroleum' BISD 34S/160\$5.2.9, and 'EEC-Regulation on Imports of Parts' BISD 37S/132, \$5.25-5.26; 'Thailand-Restrictions on Importation of and Internal Taxes on Cigarettes' DS10/2, adopted on 7 November 1990, BISD 37S/227, \$86-88; and more recently, 'US-Measures Affecting' DS32/R, adopted 19 June 1992, 85.3.9. The existence of potentially GATT-inconsistent natioual legislation that is not mandatorily applied i.e., application is left to the discretion of contracting parties - is not necessarily a violation of the national treatment rule. On the second, a recent Panel Report concluded that "purchase regulations creating such a risk must be considered to be according less favourable treatment within the meaning of Article III:4." "EEC-Payments and Subsidies paid to Processors and Producers of Oilseeds and Related Animal-Feed Proieins. "See L/6627, adopted on 25 January 1990, BISD 37S/124-125, \$\$137-141 (emphasis added).
} 
as non-charge elements. Both provisions must be interpreted the same way:

Art.III:2 ... protect[s] expectations on the competitive relationship between imported and domestic products. Art.III:4, which is the parallel provision of Art.III dealing with the non-charge elements of internal legislation, has to be constried as serving the same purpose. Article III:4 would not serve this purpose if [an other] interpretation were adopted, since a law, regulation or requirement could then only be challenged in GATT after the event as a means of rectifying less favourable treatment of imported products rather than as a means of forestalling it. ${ }^{21}$

Thus, 'non-charge policies' must be applied in a non-discriminatory way to like products, and GATT contracting parties must guarantee ex ante, rather than ex post, competitive conditions between imported and domestic products. Article III:4 pertains to laws, regulations or requirements. GATT Panels have concluded that 'requirements' comprise not only those which an enterprise is legally bound to carry out, but also those which an enterprise voluntarily accepts in order to obtain an advantage from the government. ${ }^{22}$

\section{Practices that have been examined under Article III}

A number of competition policy-related disputes where it was alleged that certain measures violated Art.III have been brought to GATT. Examples include impediments in distribution such as discriminatory offer of points of sale, marketing requirements, and pricing policies. With respect to measures affecting the distribution of imported products, a 1992 Panel Report concluded that a U.S. requirement that imported beer and wine be sold only through in-state wholesalers or other middlemen was contrary to Art.III:4, as some domestic like products were permitted to be sold directly to retailers. ${ }^{23}$ A Canadian requirement that foreign investors were to buy exclusively

\footnotetext{
${ }^{21}$ Panel Report on "US-section 337", BISD 36S/387, \$5.11-5.13, emphasis added.

2 See the Panel Report on "EEC-Regulation on Imports of Parts and Components", L/6617, adopted on 16 May 1970 , BISD 37S/132 \$5.21. The expansive interpretation of the word "requirement" could be based on the term "affecting" used in Art.III:4. There has been a coherent approach by GATT panels dealing with the interpretation of Art.III:4. A 1958 GATT panel first stated: "the text of paragraph 4 referred ... to laws and regulations and requirements affecting internal sale, purchase, etc., and not to laws, regulations and requirements governing the conditions of sale or purchase. The selection of the world "affecting" would imply ... that the drafters of the Article intended to cover in paragraph 4 not only the laws and regulations which directly governed the conditions of sale or purchase but also any laws or regulations which might adversely modify the conditions of competition between the domestic and imporred products on the material market." Panel Report on Italian Discrimination, BISD 7S/60, \$11-13 (emphasis added).
}

23 'US-Measures Affecting Alcoholic and Malt Beverages' DS32/R, adopted 19 June 1992, \$5.30 - \$5.33. 
from Canadian suppliers was also deemed to be inconsistent with Art.III:4. ${ }^{24}$

Another Panel Report noted that by allowing domestic beer access to points of sale not available to imported beer, Canada accorded domestic beer competitive opportunities denied to imported beer in a manner inconsistent with Art.III:4. In this case, imported beer had to be delivered by/through the Canadian liquor boards, while domestic beer could use private delivery. Although Canada argued that in this respect liquor boards were operating on a commercial basis (see the Article XVII discussion below), the Panel concluded that this requirement was also inconsistent with Art.III:4. This Panel also dealt with packaging requirements pricing restrictions. On the former, Canada required that imported beer be shipped in six-pac $r$ :n main:rs. As this affected sales in outlets where six-packs were not offered for sale, the Panel aga .n ...aluded that this requirement was inconsistent with Art.III. With respect to pricing policies, the 1 a rel stated that the maintenance by an import and sales monopoly of a minimum price for an imported product at a level at which a directly competing, higher-priced domestic product was supplied was also inconsistent with Art.III:4. ${ }^{25}$

Various measures implying discriminatory access to distribution systems have therefore been found to be inconsistent with GATT obligations. The foregoing measures qualify as 'noncharge' policies and thus fall under the scope of Art.III:4. If such discrimination is inconsistent with the importing country's competition law, the matter raised by the exporting vintracting party indirectly concerns the non-enforcement of such law. If it is not inconsistent - e.g., because of an antitrust exemption - the resulting discrimination can nonetheless be addressed in GATT. ${ }^{26}$ In practice, a concern that is often raised regarding the contestability of markets relates to antitrust exemptions and domestic monopolies/cartels. Neither are GATT-inconsistent per se, but the latter are subject to GATT non-discrimination disciplines. These are laid out in Article XVII.

\footnotetext{
24 Panel Report on "Canada-Administration of the FIRA" BISD 30S/160, $\$ 5.9-\$ 5.11$.

25 'Canada-Import, Distribution .. ' DS17/R, adopted on 18 February 1992, §5.5; §5.12-\$5.14; §5.4; 55.30. Maximum-price requirements in the context of the Panel Report on "US-Measures Affecting ..." have also been found to be GATT-inconsistent, \$5.59.

${ }^{26}$ As Sir Leon Brittan lucidly puts it: "we cannot seriously expect the authorities in our export markets to stand back and bless these authorized activities merely because we have exercised our jurisdiction" (Brittan, 1991, p. 4).
} 


\section{Article XVII: State-Trading Enterprises}

Art.XVII pertains to: (i) state-owned enterprises, (Art.XVII: 1a); (ii) any enterprise that has been granted formally or in effect exclusive or special privileges (XVII:1a); (iii) marketing boards (Interpretive Note, Art.XVII:1); (iv) any enterprise under the jurisdiction of a contracting party (XVII:1c); and (v) import monopolies (XVII:4b). ${ }^{n}$ The right of contracting parties to maintain or establish state-trading enterprises or to offer exclusive privileges is not at all prejudged by the General Agreement. ${ }^{28}$ The basic obligation imposed on contracting parties is that they should ensure that the enterprises covered by Art.XVII not act in a manner inconsistent with the general principle of non-discrimination. ${ }^{29}$ The crucial question is what is meant by the reference to non-discrimination - only MFN, or national treatment as well. While the MFN obligation applies unambiguously, an early Panel concluded that national treatment was not covered. ${ }^{30}$ Subsequent Panels reaffirmed this, albeit in a more qualified manner. ${ }^{31}$ However, a recent Panel concluded that a contracting party's right to establish an import and sales (distribution) monopoly does not

\footnotetext{
${ }^{27}$ Panel Report on "Notification of State-trading enterprises", L/970, adopted on 13 May 1959/142. Import monopolies are also dealt with in Art.II:4 which limits the level of protection to that implied by the relevant schedule of tariff concessions. Art.II:4 speaks of monopolies maintained or authorized formally or in effect, a verbatim reproduction of Art.31 of the Havana Charter, in the light of which it has to be interpreted (Interpretive Note Art.II:4). The words 'in effect' suggest that private enterprises that have effectively developed an import monopoly may also be covered to the extent that no government action has been taken to dismantle them (e.g., via the application of domestic antitrust). See also Jackson (1969, p. 355) on this point.
}

22 As noted by the Committee on the Legal and Institutional Framework of the GATT: "nothing in the General Agreement prevents a contracting party from establishing or maintaining state trading enterprises, nor does the General Agreement sanction discrimination against state trading enterprises which are, in this regard, placed on the same basis as any other entciprise". L/2281, \$9-10.

29 Art.XVII:1. See also Preparatory Work, Geneva, EPCT/160, §5-6; EPCT/A/PV.14. Even in the context of the Havana Charter a parallelism was sought between private firms and state-trading enterprises by the drafters, see Jackson (1969), p. 334. Art.XVII: 1(b) does not establish a separate legal obligation, but provides the mechanism for the implementation of the obligation contained in Art.XVII:1(a). Panel Report on "Canada-Administration of the FIRA," BISD 30S/163, \$5.16.

${ }^{30}$ See Jackson (1969), p. 346 on MFN. The Panel report ou "Belgian Family Allowances" decided that the scope of Art.XVII "did not extend to matters dealt with in Art.III." G/32, adopted 7 November 1952, BISD 1S/59, 84.

31 'Canada-Administration of the FIRA' BISD 30S/16S, \$5.16: "[T]he Panel saw great force in Canada's argument that only the most-favoured-nation and not the national treatment obligations fall within the scope of the general principles referred to in Art.XVII: 1(a). However, the Panel did not consider it necessary to decide in this particular case whether the general reference to the principles on nondiscriminatory treatment referred to in Art.XVII: 1 also comprises the national treatment principle since it bad already found the purchase undertakings at issue to be inconsistent with Art.III:4." 
entail the right to discriminate against imported products inconsistently with Art.III:4. ${ }^{32}$ If national treatment were not to apply in the context of import-cum-distribution monopolies, then contracting parties would have an incentive to have recourse to such monopolies and circumvent their Art.III obligations.

Three qualitatively different legal obligations are imposed by Art.XVII, depending on the type of entity involved. First, as far as import monopolies are concerned, cortracting parties are obliged (upon request of contracting parties having a substantial traae in the frorluct concerned) to "inform the CONTRACTING PARTIES of the import mark-up on the product during a recent representative period, or, when it is not possible to do so, of the price charged on the resale of the product". ${ }^{33}$ Second, in their purchases or sales involving either imports or exports, state-owned enterprises, marketing boards and enterprises granted exclusive privileges (whether de jure or de facto), contracting parties must ensure that such firms act in a manner consistent with the general principles of non-discriminatory treatment presc:ibed in the General Agreement for governmasntal measures affecting imports or exports by private traders (Art.XVII:1(a)). Given the applicability of the non-discrimination principle in the context of Art.XVII, there is arguably a parallel between 'governmental measures' and 'all laws, regulations and requirements' of Art.III:4. Consequently, the obligation imposed on contracting parties in respect of the three aforementioned types of categories of enterprises should read as follows: a contracting party should abide by the nondiscrimination principie in respect of governmental measures (be it laws, regulations or requirements in the sense of Art.III:4) that affect imports or exports by private traders (that is, not only directly governs, but also might adversely modify the conditions of competition). This is a clear obligation

\footnotetext{
${ }^{32}$ Panel Report "Canada-Import, Distribution" DS17/R, adopted on 18 February 1992, §5.15. In this case the measure in question was a Canadian regulation affecting the internal transportation of beer. An earlier, related, Panel recognized that there was "great force in the argument that Art.III:4 was also applicable to state-trading enterprises at least when the monopoly of the importation and monopoly of the distribution in domestic markets were combined. This interpretation was confirmed a contrario by the wording of Art.III 8(a), "Canada-Import, Distribution..' L/6304, adopted on 22 March 1988, BISD 35S/90, \$4.26. Art.III:8(a) states that laws, regulations or requirements relating to government procurement of products for governmental use (i.e., not for resale) are not subject to national treatment. For those contracting parties that are signatories of the government procurement code, strengthened disciplines are provided in that context. The words 'at least' suggest that whenever the activities of a monopoly have an effect on the treatment of imported products, Art.III applies. It remains to be determined in future GATT case-law precisely what effects are relevant.
}

${ }^{33}$ See Art.XVII:4b. CONTRACTING PARTIES refers to all contracting parties acting jointly. This requirement pertains only to products where no tariff concessions have been negotiated. 
of result: contracting parties are free to adopt any measure provided that it is consistent with the principle embodied in Art.III. ${ }^{34}$ Third, Art.XVII: 1(c) requires contracting parties to ensure that no enterprises under their jurisdiction be prevented from acting in accordance with the nondiscrimination principle. ${ }^{35}$ This means that there is no positive obligation imposed on contracting parties to ensure that private enterprises act in conformity with the principle. Private enterprises are permitted to behave in an Art.III inconsistent way. It is not the action of private enterprises but the action of governments that is a matter of concern in Art.XVII. ${ }^{36}$

\section{Article XI: Elimination of Quantitative Restrictions}

Quantitative restrictions (QRs) are relevant in the context of this pay ir because they are frequently used by firms to restrict market access, but are enforced by governments. Articles XI-XIV provide the legal framework addressing QRs: Article XI forbids QRs; Article XII exceptionally permits $Q R s$ used fo- balance-of-payments (BOP) reasons; Article XIII requires that such QRs apply on a nondiscriminatory (erga omnes) basis; and Article XIV provides that if $Q R s$ are applied for BOP reasons the nondiscrimination requirement may be waived by the CONTRACTING PARTIES (Jackson, 1969, p. 308). The basic obligation imposed on contracting parties in Art.XI: 1 is to refrain from introducing or maintaining QRs. ${ }^{37}$ Import quotas constitute

\footnotetext{
${ }^{34}$ Firms granted exclusive privileges are also to make purchases nr sales solely in accordance with commercial considerations. An interpretive note states that "the wharging by a state enterprise of different prices for is sales of a product in different markets is not precluded [by Art.XVII], provided that such different prices are charged for commercial reasons, to meet conditions of supply and demand in export markets." See also Dam (1970).

${ }^{35}$ The applicability of the non-discrimination principle in the context of Art:XVII:1(c) was acknowledged in the Panel Report on "Canada-Administration of the FIRA", BISD 30S/159, \$5.16,

${ }^{36}$ As Jackson (1969, p. 330) points out, if all private firms in a contracting party decide to cease sales or purchases across their national border, then the flow of international trade for that country might dry up but no violation of the GATT would have occurred.

37 Article XI: 1 states: "No prohibitions or restrictions other than duties, taxes or other charges. whether made effective through quotas, import or export licences or other measures, shall be instituted or maintained by any contracting party on the importation of any product of the territory of any other contracting party or on the exportation or sale for export of any product destined for the territory of any other contracting party". Article XI:2 lists the permissible exceptions.
} 
import restrictions within the meaning of Article XI: 1 whether or not they actually impede imports. ${ }^{38}$ Art.XI is therefore similar to Art.III in that its purpose is to establish competitive conditions, independent of trade effects. However, Arts.III and XI differ in two respects. First, the only obligation that can be imposed regarding $Q R s$ is nondiscrimination between foreign products. The question of discrimination between domestic and imported produ is does not come into play. Second, whereas Art.III:4 deals with "all laws, regulation or requirements" that might lead to treatment less favourable to imported products than that accorded to domestic ones, Art.XI addresses "prohibitions or restrictions other than duties, taxes or other charges, whether made effective through quotas, import or export licences or other measures".

While the terms quotas, import and export licences are unambiguous, this cannot be said for 'measures'. A recent GATT-panel noted that measures must be governmental and that the drafting history of the GATT suggested that the drafters were primarily concerned with the effectiveness of the measures. ${ }^{39}$ The Panel therefore did not feel bound by the legal qualification of the measure in question, but focused its attention on its effect. In this case the measure in question was a non-mandatory "administrative guidance" by MITI, based on consensus and peer pressure. While the Panel found that this was a measure under Article XI, it emphasized that its conclusion was limited to this specific case and should not be construed to encompass all 'administrative guidance'. Another Panel concluded that in determining whether specific nonmandatory measures contravene Article XI, two criteria have to be satisfied: "First, [the existence of] reasonable grounds to believe that sufficient incentives or disincentives existed for nonmandatory measures to take effect. Second, [that] the operation of the measures to restrict exports [is] essentially dependent on Government action or intervention". ${ }^{40}$ Non-mandatory government

\footnotetext{
38 "The mere existence of a $Q R$ is presumed to cause nullification or impairment not only because of its trade effects but also because it would lead to increased transaction costs and would create uncertainties which could affect investment plans, "EEC-Payments and Subsidies to Processors and Producers of Oilseeds and Related Animal-Feed Proteins', L/6627, adopted on 25 January 1990, BISD 37S/86 and 'Japanese Measures on Imports of Leather', adopted on 15/16 Maay 1984, BISD 31S/113. See also 'Brazilian Import Taxes', adopted on 30 June 1949, Vol.II/184-5.

${ }^{39}$ See "Japan-Restrictions on Imports of Certain Agricultural Products", adopted on 22 March 1988, I/6253, BISD 35S/242, \$5.4.1.4.

40 'Japan-Trade in Semiconductors', adopted on 4 May 1988, L/6309, BISD 35S/153-4, pp.154-5, \$\$108-109. The natter of concern was a minimum export price that the Panel found to operate in the form of a mandatory requirement.
} 
measures can accordingly violate Article XI.

A number of measures have been found to be inconsistent with Article XI:1: (1) a clause in the legislation of the United States which prohibited, with certain exceptions, the importation or public distribution in the U.S. of a copyrighted work consisting preponderantly of non-dramatic literary material in the English language; ${ }^{41}$ (2) the provisions of the U.S. Marine Mammal Protection Act that prohibit imports of tuna if harvested in a way that does not respect the standards imposed by the legislation; ${ }^{42}$ (3) minimum import price systems (enforced by additional security); ${ }^{43}$ and (4) minimum export price systems. ${ }^{4}$

The General Agreement also recognizes that $Q R s$ may be used by state-trading enterprises. An Interpretative Note in this regard states that throughout Articles XI, XII, XIII, XIV and XVIII, the terms import or export restrictions include restrictions made effective through state trading operations. The Note refers to 'restrictions made effective through State-trading operations' and not to 'import restrictions' in an attempt to ensure that contracting parties cannot escape their obligations with respect to private trade by establishing state-trading operations. ${ }^{45}$

\section{Non-violation: Article XXIII on Nullification and Impairment}

The foregoing has looked at relevant specific GATT obligations. We now tum to GATT's dispute settlement procedures, which are broader in scope. There are three grounds for a contracting party to invoke GATT dispute settlement procedures and claim that benefits accruing

\footnotetext{
41"US-Manufacturing Clause", L/5609, adopted on 15/16 May 1984, BISD 315/91, \$42(i).

42"US-Restrictions on Imports of Tuna , DS21/R (unadopted), \$\$5.17, 5.18, 5.36.

43 "EEC-Programme of Minimum Import Prices, Licences and Society Deposits for Certain Processed Fruits and Veretables", L/4687, adopted on 18 October 1978, BISD 25S/99-100, \$4.9.

"Japan-Trade in Semi-conductors", BISD 35S/153, \$105.

4 As explained in a GATT-panel: "this was a recognition of the fact the in the case of enterprises enjoying a monopoly of both importation and distribution in the domestic market, the distinction normally made in the General Agreement between restrictions affecting the importation of products and restrictions affecting imported products lost much of its significance since both types of restriction could be made effective through decision by the monopoly. The Panel considered that systematic discriminatory practices of the kind referred to should be considered as restrictions made effective through 'other measures' contrary to the provision of Article XI:1." 'Canada-Import, Distribution' BISD 35S/89, 84.24. See also 'Japan-Restriction on Imports of Certain Agricultural Products' BISD 35S/229, $\$ \$ 5.2 .2 .2$.
} 
to it directly or indirectly under the General Agreement are being nullified or impaired or that the attainment of any objective of the General Agreement is being impeded. These are: (a) the failure of another contracting party to carry out its obligations under the Agreement; (b) the application by another contracting party of any measure, whether or not it conflicts with the provisions of this Agreement; or (c) the existence of any other situation.

The first category (a) constitutes a 'violation' complaint. i.e., it can be invoked if a government policy or measure is deemed to violate a specific GATT Article. A.t.XXIII:1(a) is not applicable to private anticompetitive practices, as these per se do not violate any GATT provision. One Article that must be discussed in this connection is Article XXIX (entitled the Relation of this Agreement to the Havana Charter). Art.XXIX:1 stipulates that: "contracting parties undertake to observe to the fullest extent of their executive authority the general principles of Chapters I to VI inclusive and of Chapter IX of the Havana Charter pending their acceptance of it in accordance with their constitutional procedures." Chapter V of the Havana Charter ${ }^{46}$ (HC) is dedicated to Restrictive Business Practices (RBPs). It contains a potentially allencompassing list of RBPs that must be addressed by contracting parties whenever they "have harmful effects on the expansion of production or trade and interfere with the achievement of any of the other objectives set forth in Article 1."47 The GATT entered into force through the Protocol of Provisional Application in the expectation that the HC would be ratified in the near future. This expectation dici not materialize, and a proposal to delete Art. XXIX in 1955 was adopted unanimously. ${ }^{48}$ However, failure by one contracting party to ratify this change to the General Agreement led to the continued inclusion of the Article in the text of the GATT. ${ }^{49}$ Although Art. XXIX is technically still a part of the General Agreement, contracting parties are not bound by obligations contained in Chapter 5 of the HC. This point of view has been accepted

\footnotetext{
${ }^{46}$ The Havana Charter was supposed to establish the International Trade Organization. It never entered into force because the US Congress refused to ratify it (see Jackson, 1969, pp.36ff).

${ }^{47}$ See the Havana Charter, Article 46, reproduced in UN Doc. E/Conf.2/78; Art. 1 states the objectives of the Charter, which include trade expansion and income growth.

${ }^{48}$ BISD 3S/240.

${ }^{49}$ See Protocol Amending Part I and Articles XXIX and XXX of the GATT, GATT-Status of Legal Instruments p.2-7.1.
} 
in the GATT case-law. ${ }^{50}$

Notwithstanding the 1955 attempt to eliminate the link to the HC, Gs TT contracting parties established a Group of Experts in 1958 to study whether and to what extent the GATT should deal with RBPs. ${ }^{31}$ Members of the Group were unable to reach consensus in their 1960 report. A majority considered that it would be unrealistic at that moment to recommend the negotiation of multilateral disciplines to control RBPs. However, they recognized that RBPs could have a harmful effect on international trade, and proposed that bilateral consultations take place between interested parties on specific practices. The suggested procedure was to keep this outside the realm of Article XXIII (dispute settlement): "[members of the Group] were not competent to judge ... whether the provisions of Article XXIII would be apjlicable. However, the majority were convinced that, regardless of the question whether Article XXIII could legally be applied, they should recommend to the CONTRACTING PARTIES that they take no action under this Article. " 52 A minority proposed a multilateralized procedure to address RBP-related issues. A group of experts would deal with those issues that could not be settled bilaterally, and would submit a report to the GATT secretariat, which would in tum report annually to the CONTRACTING PARTIES. The disagreement led to a decision to provide a forum for consultations in this area, upon request, and appoint a group of experts on RBPs "to be convened when appropriate"..$^{53}$ While the adopted report contains two differing opinions on the possibility to address RBPs in the context of Article XXIII, there was agreement on one srucial point: RBPs could have harmful effects on world trade. Moreover, even the majority refrained from addressing the crucial question of the general applicability of Article XXIII in this context.

Virtually no actions were taken subsequent to the adoption of the report of the Group of

\footnotetext{
so "The Panel noted that the deletion of Article XXCX of the General Agreement was proposed in 1Sj5 and accepted by all but one contracting party, and that - although this Article is technically still in force - it refers to an instrument which itself has never been implemented and the acceptance of which is no longer pending as is assured in Article XXIX. This leaves considerable doubt as to the manner in which its provisions would have been interpreted if they had entered into force." See "Canada-Administration of the FIRA", BISD 3OS/161 \$5.12.

${ }^{31}$ BISD, 7S/29.

S2 BISD, 9S/170 ff.

53 Tbid.
} 
Experts, and virtually no attempts have been made by contracting parties to address RBPs within the existing GATT legal framework. The one exception concerned EC allegations that certain measures taken by the Japanese government were inhibiting the importation of products manufactured in the EC. In its request for the establishment of a panel, the EC claimed that benefits of negotiations with Japan had not been realized because of a number of factors made it extremely difficult for EC products to penetrate the Japanese market. Factors mentioned included the marked concentration and interlinking of the structure of production, finance and distribution in Japan, which made it difficult for foreign suppliers to establish distribution channels. ${ }^{54}$ The EC argued that such factors nullified and impaired benefits that would otherwise have accrued to it. The discussion that followed in the GATT Council failed to shed light on this case and ultimately the EC decided to refrain from pursuing it. ${ }^{\text {ss }}$ In this case the EC qualified its complaint as a 'situation complaint' under Article XXIII:1(c) (Bronckers, 1985, p.151). It is questionable whether Article XXIII:1(c) can provide an appropriate forum to address concerns related to RBPs. ${ }^{56}$ GATT drafting history suggests that this option was designed to address exceptional circumstances/emergency situations. No panels have ever been established to examine a situation complaint. $^{57}$

The only forum for competition policy-related disputes where no specific GATT Articles are violated therefore is a non-violation complaint under Article XXIII:1(b). The non-violation provision has an autonomous function in the GATT dispute-settlement system. Most non-violation

\footnotetext{
See GATT Doc. L/5479.

ss see GATT Doc.C/M/167 p.9.

s6 The first sentence of Article XXIII:2 reads: "If no satisfactory adjustment is effected between the contracting parties concerned within a reasonable time, or if the difficulty is of the type described in paragraph 1(c) of this Article ...". Attempts to reach a satisfactory adjustment is not a precondition to seek the establishment of a Panel. Taken into account that the general rules, as embodied in Article XXII-XXIII of GATT, require that for a Panel to be established bilateral consultations must have taken place, "situation complaints" should be regarded only in exceptional circumstances as a possible means of requesting establishment of a Panel. The conditions under which complaints could be qualified as "situation-complaints" have never been specified in GATT case law.

${ }^{57}$ Except for the aforementioned case, only once was there a threat of making use of this provision: following the accession of the United Kingdom to the EC, Canada's access opportunities to the UK market were substantially reduced. Canada felt that Article XXIII:1c was the appropriate forum to address such issues insofar as negotiations under Article XXIV:6 with the EC were expected to be unsuccessful. Subsequently, however, Canada dropped the case. GATT Docs. L/4107, L/M/101, C/W/250, C/W/251. Petersmann (1991. p. 227) has argued that situation complaints are no longer an appropriate instrument for adjusting the GATT framework of rights and obligations.
} 
cases brought before GATT panels have involved the nullification or impairment of a negotiated tariff concession by the introdiction of a subsidy that could not have been reasonably anticipated by the other party at the time the tariff binding was conceded. However, this is by no means the only type of action that might give rise to non-violation complaints. ${ }^{58}$ As Petersmann (1991, p.225) points out, "non-violatic.ı complaints are based on ... legal principles of effectiveness of concessions, reciprocity and bona fide protection of reasonable expectations." Reasonable expectations are created by concessions negotiated at any point in time. The Vienna Convention on the Law of the Treati-s ${ }^{39}$ obliges signatory states to refrain from acts frustrating the object of the treaty they signed (Art.18) and recognizes, in more general terms, that all treaties must be performed in good faith (Art.26). Taken into account that non-violation complaints aim to protect the competitive conditions established by agreed tariff concessions, any government measure that offsets such concessions can, in principle, be brought before GATT as a non-violation complaint under Art. XXIII:1(b).

For anti-competitive practices to be the subject-matter of a non-violation complaint three conditions must be met: (i) the measure must be applied by a government; (ii) it must alter the competitive conditions established by the agreed tariff bindings; and (iii) the measure could not have been reasonably anticipated at the time the tariff concessions were negotiated. Business practices that are not subject to any government involvement are excluded from the scope of a non-violation complaint. There is some ambiguity, however, regarding the extent of the government involvement that is necessary. Article XXIII:1(b) speaks of 'application of any measure' that nullifies and impairs benefits. The term 'measure' suggests that not only formal laws and regulations are included but also other forms of government action that are necessary to make the government choice operative. In this respect, the interpretation of the terms 'requirements' and 'measures' in GATT case-law provides useful guidance. The term 'application', suggests

\footnotetext{
${ }^{58}$ In the GATT legal system, Article XXVIII (modification of sct.edules) for example, can also provide a forum for such complaints.

${ }^{59}$ Reprinted in International Legal Materials, 8, 679, 1969. The Convention applies only to subsequently concluded treaties. The portion governing general interpretation of trcaties is considered to be codifying customary international law and therefore applies to treaties concluded before its entry into force and is binding even on countries that are not parties to it.
} 
that positive action is required. If correct, then the mere tolerance by a government of a RBP is not sufficient grounds for a non-violation complaint. However, if tolerance is reflected in a positive (specific) action, the first criterion will be satisfied. An example could be an exemption by the competent anti-trust authorities granted to private enterprises that effectively redı'ces market access opportunities for products of third countries by establishing difficult to penetrate distribution channels. In such cases, if the action (exemption) could not have been reasonably anticipated at the time market access conditions were negotiated, a contracting party might bring a non-violation complaint.

The 'application of a measure' is, of course, the means through which nullification and impairment of henefits might occur. Non-violation complaints were designed to address the concern of contracting parties relatilig to modification ${ }^{60}$ of the agreed competitive conditions (based on the negotiated tariff , incession') through subsequent government action. Such action is likely to take the form of positive behaviour, and Article XXIII:1(b) reflects this. If, however, the accent is placed on the means that lead to the prohibited result rather than on the prohibited result as such, one might end with the inconsistent conclusion that only some forms of government action leading to nullification can be addressed and others not. A teleological approach is appropriate here. As the key criterion is nu!lification and impairment, the means that might lead to this result should be interpreted in a flexible way. ${ }^{61}$ In this sense, not only positive action but also passive tolerance of a RBP, to the extent that it nullifies or impairs established competitive conditions, could give rise to a non-violation complaint, and this independently of the legal action that might be taken on the domestic plane.

Even if one accepts that passive tolerance is sufficient, the second neressary condition illustrates a clear limitation of the GATT as regards bringing competition policy-related disputes. RBPs producing extraterritorial effects cannot be brought before a GATT panel. This is because in practice non-violation complaints aim at preserving the competitive conditions established on the basis of negotiated tariff concessions, which concern only import tariffs. Export concessions

\footnotetext{
${ }^{\infty}$ In the negative sense, of course, since nothing prevents contracting parties from improving unilaterally the agreed market access opportunities.

${ }^{61}$ After all, flexibility is not only one of the key concepts of the interpretation of GATT-law, but probably one of the main reasons of its success.
} 
are not negotiated in GATT. Consequently, only practices that deny market access opportunities in the domestic market can be the object of such complaints.

Tuming to the third condition, 'unexpectedness', Panels have interpreted the scope of the protection of 'reasonable expectations' under GATT as follows. First, the balance of concessions is the highest ranking norm that has to be protected in the GATT system against both legal and illegal actions disturbing this balance. Second, contracting parties can reasonably expect that this balance will not be nullified or impaired, failing evidence to the contrary. ${ }^{62}$ The content of the term 'reasonabie expectations' has not been interpreted in GATT case-law. Panels tend to follow a case-by-case approach. Indeed, one can question whether it is appropriate at all to define specific criteria determining the reasonableness of expectations. The answer could be provided through a procedural rule: if 'failing evidence to the contrary' is always to be interpreted as a shift of the burden of proof on the contrasting party trying to reject the argument that something was reasonably expected, then 'reasonable expectations' will be perceived to be always present and therefore protected when a concession is negotiated, unless the contracting party that allegedly modified the value of the concession provides evidence to the contrary. If the term 'evidence' is given its ordinary meaning, then the imposed standard of proof on the contracting party invoking the unreasonableness of expectations is high. ${ }^{63}$ The substantive content of the term 'reasonable ex'yectations' can therefore be argued to be of secondary importance, since these exist until proven unreasonable. If this interpretation is accepted, the onus will be on the contracting party that alters the value of the concession to show that at the time it was negotiated serious reasons should have led the other contracting party to believe that the agreed level of

62 "[T]he recognition of the legitimacy of an expectation relating to the use of production subsidies in no way prevents a contracting party from using production subsidies consistently with the General Agreement; it merely delineates the scope of the protection of a negotiated balance of concessions." See Report of the Panel on "EECPayments and Subsidies Paid to Processors and Producers of Oilsecds and Related Animal Feed Proteins", adopted on 25 January 1990, L/6627, BISD 37S/128, \$148. Also, "A contracting party which has negotiated a concession under Article II may be assumed, for the purpose of Article XXIII, to have a reasonable expectation, failing evidence to the contrary, that the value of the concession will not be nullified or impaired by the contracting party which granted the concession by the subsequent introduction or increase of a domestic subsidy on the product concerned." Report of the Working Party on "Other Barriers to Trade", BISD 3S/224, $\$ 15$.

* The French translation of the term "evidence" in the GATT Anti-Dumping Code for example is "elements de preuve". 
competitive conditions would eventually be reduced (modified negatively in the future). ${ }^{64}$

\section{Maintaining Competitive Couditions: The Limits of GATT}

The examination of the case law in the context of Articles III, XVII and XI demonstrates that complaints may be brought against business practices if they are supported by the government and if this disturbs the competitive conditions established by the GATT regime. In principle, such support may consist of passive tolerance (de facto exclusion from competition laws or the nonenforcement of such laws) or more active involvement (i.e., antitrust exemptions). Active support may also take the form of subsidies, taxes or trade barriers. Two paths are available in principle to dispute government support of anticompetitive business practices. The first is to charge that a contracting party has violated a GATT obligation. The second is to bring a non-violation complaint, arguing that a measure that is not GATT-inconsistent has nonetheless led to the nullification or impairment of a existing tariff concession, or impedes the realization of an objective of the General Agreement. Under current GATT rules and principles, anticompetitive business practices that are passively supported by governments can only be addressed through a non-violation complaint. Active support will usually lead to a violation complaint (see ex ample below). In the first case the initial legal relationship between the government and the enterprise(s) suffices in terms of bringing a case to GATT. In the second case it does not; the government must also impose measures that: (1) support the business practice; and (2) violate a GATT obligation.

If, for example, an antitrust exemption underlies the existence of a cartel, the exemption

\footnotetext{
(4) One may nonetheless speculate as to what could come under the term 'reasonable expectations'. Can, e.g., a contracting party reasonably expect another GATT contracting party to respect its declarations in other international fora? If so, then "The Set of Multilaterally Agreed Equitable Principles and Rules for the Control of Restrictive Business Practices" concluded at the UN (reproduced in International Legal Materials, 19, 1980, p. 813) might be the basis of reasonable expestations between GATT contracting parties that they will not alter the value of negotiated concessions (after 22 April 1980, the date of adoption of the Set) through behaviour inconsistent with the set of agreed principles. Notwithstanding the non-binding character of the UN resolutions, the argument can be made that such acts oblige signatories at least to act in a non-inconsistent way. For a discussion of this "anti-inconsistency" principle, see Baade (1980). Roessler (1978, p. 40) calls such non-binding rules de facto agreements and defines them as "declarations intended to give ground to expect performance or forbearance of witions without creating legal rights and obligations." This has been supported by Berrisch (1991). The logical counter-argument is, of course, that limits must be placed on the application of this reasoning, as otherwise everything under the sun might be brought before GATT. However, the issue here is not whether a convention signed outside GATT legitimises a cause of action in GATT, but simply what can be understood to cunstitute a reasonable expectation. The cause of action in the GATT context is the nullification or impaiment of the agreed balance of concessic:ns.
} 
in itself will not be sufficient for a violation case. What is necessary is that the government supports the operation of the cartel through other policies. Articles III, XVII, or XI may then come into play. Take the case of a cartel tiat is legally formed under a country's antitrust law. This constitutes active support by the government. If the cartel consists of all or most of the firms in the industry, it can be argued to be subject to Art.XVII in the sense that the exemption is a privilege granted by the government. ${ }^{\text {os }}$ The cartel will then be subject to the nondiscrimination principle and is required to make sales or purchases on the basis of commercial considerations. If it can be shown that it does discriminate or does not follow commercial considerations, the action may be found to violate the GATT. Moreover, if the government protects the cartel through tax exemptions, trade barriers or other policies that imply discrimination against foreign products, these practices may be attacked through Art.III. ${ }^{66}$ Similarly, if it has a distribution monopoly it must respect Art.III. To the extent that such government 'support services' are necessary to the survival of the cartel, the anti-competitive practice may be eliminated. ${ }^{67}$ If $Q R s$ are used to support the cartel, Art. XI may be violated. Finally, recourse might be made to a non-violation complaint based upon the non-enforcement or non-existence of competition legislation, or (in the context of the present example) that an antitrust exemption is a government measure in the sense of Article XXIII:1(b).

Non-violation constitutes the primary avenue to address competition policy-related issues through GATT. The only possibility that exists in principle for bringing such cases to GATT as violation complaints is to argue that competition policy enforcement or nonenforcement is a de facto subsidy to a domestic industry. Trachtman (1993) has argued exactly this, making a case that exemptions or non-enforcement constitutes what he calls a 'regulatory subsidy' and as such could be the subject of nullification and impairment claims, and may be countervailed once

\footnotetext{
6s Art.XVII speaks of state trading enterprises or enterprises granted special privileges. As a result it is unclear whether its disciplines apply to a cartel, and this is something to be determined by a Panel. In many circumstances a government sanctioned cartel will exert substantial market power, if not imply effective monopolization of a market. If the industry has an import/export monopoly Art.XVII applies of course.

* As noted earlier, GATT case law has made clear that it is not necessary for there to be actual imports.

ngain, the anticompetitive practice itself is not addressed. But this is irrelevant to the issue at hand, as in many instances such practices are supported by government actions that may violate GATT obligations.
} 
they are identified. Abstracting from the issue of whether such government actions can be considered as subsidies for purposes of the GATT and the GATT Subsidies Code - a question that is unlikely to be answered in the affirmative by a panel - this does not appear to be a good strategy from a systemic perspective. It opens a Pandora's box, as any government action that can be argued tu have a specific impact on an industry becomes potentially countervailable. Pursuit of the non-violation strategy appears to be more preferable, as well as more feasible.

Although the scope to use GATT to address competition policy-related concerns is wider than is commonly thought, the foregoing analysis reveals that the reach of GATT is limited. Abstracting from 'traditional' trade restrictions (tariffs, antidumping, other NTMs), six 'lacunae' can be singled out. The first three of these are competition policy-specific, the remainder are more general. The issue for policymakers to determine is how important the 'holes' are. First, purely private business practices restricting access to markets that are not supported by the government cannot be attacked as a violation of GATT. Nor can they be contested through a non-violation complaint. While at first sight this would appear to be a major 'hole', in many circumstances an anticompetitive business practice will be supported by the government in some way. This may take the form of passive support or tolerance (e.g., non-enforcement of antitrust law - and/or more active forms of support (e.g., antitrust exemptions, or subsidies). As long as such support can be identified, recourse to GATT may be made. Of course, importing firms may have monoposony power vis-a-vis exporters, in which case exercise of such power is likely to enhance national welfare. The issue here is in large part empirical: how important are anticompetitive business practices that are not supported by governments? What is the national distribution of private monopsony power? We are not aware of research that has addressed this question. Our intuition is that in many, if not most, cases governments will be involved, often by restricting access to markets.

Second, competition policy per se is also not addressed by GATT, which is of course the reason why the non-violation route is the only one available to contracting parties. Clearly there are differences in national antitrust laws that affect the international 'playing field'. But there are of course a myriad of policies that do this. Again, advocates of pursuing multilateral rules on competition policies must make a convincing argument why multilateral disciplines on 
competition policies should be given priority over other policies that reduce the contestability of markets. The major example in this connection is antidumping (see Section II). If a credible argument could be made that the abolition of antidumping would follow the adoption of common competition policies, this would greatly strenthen the case of those calling for international competition rules. But, as discussed in Section II, the precondition for this to be possible appears to be that countries are ready to contemplate significantly deeper integration (including free trade) ran they have been willing to pursue in the recent past. The likelihood of this occurring in the multilateral context should realistically be considered to be low, as illustrated by the inability (or unwillingness) of the U.S. and the EC to abolish antidumping in recent free trade agreements with third countries (NAFTA and the Europe Agreements, respectively). ${ }^{68}$ It will arguably be more productive to continue to seek further liberalization of market access conditions, including policies on FDI, and continue to publicize the economic irrationality of antidumping. As emphasized by Finger (1993, Chapter 4), the only politically effective resistance to antidumping comes from domestic industries that are negatively affected by the resulting impacts on input prices and uncertainty. Multilateral attempts to tighten the rules can only have a limited effect on disciplining the use of these measures. Ultimately, dealing with antidumping is a domestic political issue.

Third, the reach of GATT is currently restricted to action or inaction by governments that affect the conditions of competition in their markets. Practices by firms on export markets or lack of regulation on the part of a government regarding behavior of firms under its jurisdiction on export markets cannot be addressed. Thus the oft encountered statement that GATT does not discipline export cartels. While true, it should be recognized that the same applies to actions by governments themselves that have detrimental effects on competition in export markets. Although export prohibitions or quantitative restrictions are forbidden under Art.XI, and export subsidies on manufactures are prohibited for industrialized countries, current GATT rules basically give contracting parties the freedom to impose tariffs on exports. They also allow for the formation

60 This is not to say that the trade-off cannot be made. The recent European Economic Area Agreement and the 1988 revision of the Australia-New Zealand Closer Economic Relations Trade Agreement illustrate that sovereign states may agree to abolish antidumping and adopt common antitrust disciplines. However, the degree of economic integration pursued by the countries involved is far-reaching and is unlikely to be feasible in the multilateral context. 
of export monopolies, the disciplines of Art.XVII in this regard being limited. This implies that contracting parties remain substantially free to attempt to shift the terms of trade in their favour. Efforts to agree to multilateral discislines on export cartels, even if successful, will have to be complemented by analogous tightening of the rules regarding the scope that exists for countries to pursue 'strategic' trade policy. The significance of the 'hole' in GATT with respent to export cartels and similar business practices is, of course, also an empirical issue. Our reading of the literature suggests that concerns about anti-competitive practices in import markets that are supported or tolerated by importing country governments tend to dominate. ${ }^{69}$

Fourth, the GATT pertains to products, not to producers. This is, of course, a reflection of the fact that it applies to merchandise trade, not to factors of production such as capital or labor, or to producers of intangibles (services, know-how, intellectual property). Many of these issues are on the agenda of the Uruguay Round. Foreign direct investment (FDI) has become increasingly important in the last decade, both in quantitative and in qualitative terms. The draft General Agreement on Trade in Services (GATS) explicitly covers FDI as a 'mode of supply'. As far as FDI in the goods sector is concemed, there will only be the Trade-related Investment Measures (IRIMs) agreement, which only pertains to policies such as local content. If the Round is concluded successfully, some 'GATT' disciplines on FDI will exist. However, such disciplines will be much more far-reaching for services than for goods. This inconsistency would appear to be one important issue for a future round.

Fifth, GATT has little to say about non-discriminatory regulations that restrict market access, e.g. limitations on the number of firms allowed to contest a market, with monopoly as an extreme. National treatment is clearly not sufficient to ensure that markets are contestable. This was recognized explicitly by the services negotiators and was reflected in the so-called market access commitments in the draft GATS. ${ }^{70}$ From a market access or contestability perspective, the weaknesses of existing GATT disciplines stems in large part from the fact that national treatment is the fundamental obligation. Expanding the negotiating agenda to go beyond national treatment

\footnotetext{
${ }^{69}$ The Strategic Impediments Initiative (SII) taiks between Japan and the U.S. are an illustration, as are similar albeit less 'formal' talks between Japan and the EC.

${ }^{\pi}$ See Hoekman (1992) for a discussion of the GATS.
} 
clearly has major implications for the General Agreement. But, if the objective is to enhance competition, going beyond existing disciplines in this regard are likely to be necessary. The GATS experience illustrates that this is feasible without abandoning the traditional GATT approach to international cooperation.

Sixth, GATT dispute settlement procedures are often criticized as being relatively ineffectual. Although rules and procedures have been improved since the launching of the Uruguay Round, and will be further strengthened if the round is concluded, the fact remains that trade sanctions are the ultimate 'stick' available to a contracting party. Such retaliation is not beneficial for the imposing country in that the costs to itself may easily outweigh the costs to the offending country that does not comply with adopted panel reports. And for small countries it is not a credible threat at all. Further improvement in the procedures to enforce GATT obligations is an important task facing negotiators. However, it is a task that must be undertaken independent of the competition policy issue. It would be disingenuous to argue that because of GATT inadequaciss in this domain (which are typically overstated) a new institutional approach is necessary for the enforcement of multilaterally agreed competition policy disciplines. After all, the same problems that arise in the GATT context can be expected to arise.

\section{Concluding Remarks}

The desirability of introducing competition policy on the agenda of a future multilateral trade negotiation depends importantly on how much weight is attached to increasing the contestability of markets. If the latter is the objective, efforts must continue to focus on moving the GATT system further towards achieving 'free market access' i.e., free trade in goods and services complemented by freedom of investment. Restrictions on market access are anticompetitive. The further countries move towards free market access, the less scope there will be for restrictive business practices to be pursued by firms on international markets.

Experience suggests that agreement on the adoption of common antitrust rules or enforcement procedures is not easily attained in a multilateral setting. It has only been achieved in a regional context, and then only in conjunction with the adoption of relatively far-reaching disciplines on other government policies (including subsidies), the abolition of barriers to trade, and substantial - 
if not total - liberalization of direct investment and other capital flows. In the absence of agreement that the objective in the GATT context should be to pursue economic integration of the EC-type, in the multilateral setting progress will be limited to further 'negative integration'. The easiest way of introducing competition policy-related concerns is then to attempt to reach agreement that certain policies should not be pursued and to extend the reach of GATT's dispute settlement mechanism to such issues. But it would arguably be better from a competition perspective to continue to focus negotiating effort on further liberalization of markets.

The extent to which the inclusion of competition policy-related disciplines requires substantive changes to current rules may be rather limited. In many instances private anticompetitive practices will be supported by governments, passively through non-enforcement or non-existence of competition policies, as well as more actively through other measures such as antitrust exemptions, subsidies, or trade barriers. As discussed above, some of these active types of support are already GATT inconsistent and can therefore be contested as being in violation with GATT obligations. Other policies, including competition policy in general, are in principle GATT legal. But, if the measures that are implemented by the government disturbs pre-existing competitive conditions that were negotiated in the GATT and were not foreseen at the time, a non-violation complaint may be brought.

Non-violation complaints are the primary avenue for bringing cases to GATT that directly attack the implementation of a country's antitrust legislation, or nonexistence thereof. Although potentially the non-violation option contained in Article XXIII of the GATT is a powerful tool, it has not yet been put to the test. Invocation of this option by contracting parties would help determine the limits of the GATT in this regard, and help identify the policies that are deemed most 'problematical'. A more intensive use of the existing GATT mechanisms, however imperfect, would help offset the current lack of data regarding the policies that have given rise to calls for introducing competition policy on a multilateral negotiating agenda. Indeed, the virtual absence of such cases could support the hypothesis that the issue is not really a first-order concern of governments. 


\section{References}

Auquier, Antoine and Richard Caves. 1979. "Monopolistic Export Industries, Trade Taxes, and Optimal Competition Policy," Economic Journal, 89, 559-81.

Baade, Hans. 1980. "The legal effects of codes of conduct for MNEs," in Norbert Horn (ed.), Studies in Transnational Economic Law: Legal problems of codes of conduct for multinational enterprises. Deventer: Kluwer.

Barcelo, John J. 1979. "The Anti-dumping Law: Repeal it or Revise it," in Michigan Yearbook of International Legal Studies. Ann Arbor: University of Michigan Press, 53-98.

Berrisch, Georg. 1991. "The Establishment of New Law through Subsequent Practice in GATT," North Carolina Journal of International Law \& Commercial Regulation, 16, 497-522.

Bhagwati, Jagdish. 1993. "Fair Trade, Reciprocity and Harmonization: The New Challenge to the Theory and Policy of Free Trade," in Alan Deardorfí and Robert Stern (eds.), Analytical and Negotiating Issues in the Global Trading System. Ann Arbor: University of Michigan Press.

Blackhurst, Richard. 1991. "Trade Policy is Competition Policy," in Competition and Economic Development. Paris: OECD.

Boner, Roger and Reinald Krueger. 1991. The Basics of Antitrust Policy: A Review of Ten Nations and the European Communities. Washington: World Bank Technical Working Paper No. 160.

Brittan, Leon. 1991. Competition Policy and Merger Control in the Single European Market. Cambridge: Grotius.

Brittan, Leon. 1992. European Competition Policy: Keeping the Playing Field Level. Brussels: Center for European Policy Studies.

Bronckers, Marco. 1985. Selective Safeguard Measures in Multilateral Trade Relations. Deventer: Kluwer.

Caine, Wesley K. 1981. "A Case for Repealing the Antidumping Provisions of the Tariff Act of 1930," Law and Policy in International Business, 13, 681.

Caves, Richard. 1987. "Industrial Policy and Trade Policy: The Connections," in Henryk Kierzkowski (ed.), Protection and Competition in International Trade. London: Basil Blackwell.

Corden, W. Max. 1987. "On Making Rules for the International Trading System," in Robert Stern (ed.), U.S. Trade Policies in a Changing World Economy. Cambridge: MIT Press.

Dam, Kenneth W. 1970. The GATT: Law and International Economic Organization. Chicago: University of Chicago Press. 
Davidow, Joel. 1981. "The Seeking of a World Competition Code: Quixotic Quest?," in O. Schachter and R. Hellawell (eds.), Competition in International Business. New York: Columbia University Press.

Feketekuty, Geza. 1992. "The New Trade Agenda," Occasional Paper No. 40. Washingion D.C.: Group of Thirty.

Finger, J. Michael (ed.). 1993. Antidumping: How it Works and Who Gets Hurt. Ann Arbor: University of Michigan Press.

General Agreement on Tariffs and Trade. 1992. "The Draft Final Act of the Uruguay Round: Press Summary," News of the Uruguay Round, No.55, December. Reprinted in The World Economy, 1993, 16:237-59.

Hoekman, Bernard. 1992. "Market Access Through Multilateral Agreement: From Goods to Services," The World Economy, 15, 707-27.

Hoekman, Bernard. 1993. "New Issues in the Uruguay Round and Beyond, " Economic Journal, (September).

Hoekman, Bernard and Michael Leidy. 1992. "Cascading Contingent Protection," European Economic Review, 36, 883-92.

Jackson, John H. 1969. World Trade and the Law of GATT. Indianapolis: Bobbs-Merrill.

Jackson, John H. 1992. "Statement on Competition and Trade Policy, " Journal of World Trade, 26 (October), 111-116.

Jacquemin, Alexis. 1993. "The International Dimension of European Competition Policy," Journal of Common Market Studies, 31:91-101.

Mattoo, Aaditya and Petros Mavroidis. 1993. "The EC-Japan Consensus on Cars: Trade and Competition Policy Trade-offs," GATT, mimeo.

Meessen, Karl. 1989. "Competition of Competition Laws," Northwestern Journal of International Law and Business, 10, 17-30.

Messerlin, Patrick. 1989. "The EC Antidumping Regulations: A First Economic Appraisal, 1980-85," Weltwirtschaftliches Archiv, 125, 563-87.

Messerlin, Patrick. 1990a. "Antidumping Regulations or Procartel Law? The EC Chemical Cases," The World Economy, 13, 465-92.

Messerlin, Patrick. 1990b. "The Antidumping Regulations of the European Community: The "Privatization" of Administered Protection," in Michael Trebilcock and Robert York (eds.), Fair Exchange: Reforming Trade Remedy Laws. Toronto: C.D. Howe Institute. 
Neven, David, Robin Nuttal and Paul Seabright. 1993. Merger in Daylight: The Economics and Politics of European Merger Control. London: CEPR.

Ostry, Sylvia. 1990. Governments and Corporations in a Shrinking World. New York: Council on Foreign Relations.

Petersmann, Ernst-Ulrich. 1991. "Violation Complaints and Non-violation complaints in Public International Trade Laws," German Yearbook of Internation ' 'Law, 34, 175-229.

Roessler, Frieder. 1978. "Law, De Facto Agreements and Declarations of Principle in International Economic Relations", German Yearbook of International Law, 21, 40-56.

Snape, Richard. 1987. "The Importance of Frontier Barriers," in Henryk Kierzkowski (ed.), Protection and Competition in International Trade. London: Basil Blackwell.

Stern, Robert M. (ed). 1993. The Multilateral Trading System: Analysis ard Options for Change. Ann Arbor: University of Michigan Press.

Tharakan, Matthew (ed.). 1991. Policy Implications of Antidumping Measures. Amsterdam: North Holland.

Trachtman, Joel. 1993. "International Regulatory Competition, Externalization and Jurisdiction," Harvard International Law Journal, 34, 48-104. 


\section{Polley Research Working Paper Serles}

Thle

WPS1208 Primary School Achievement in

English and Mathematics in

Zimbabwe: A Multi-Level Analysis

WPS1209 Should East Asia Go Regional? No, No, and Maybo

WPS1210 The Taxation of Natural Resources: Principles and Policy Issues

WPS1211 Savings-Investment Correlations and Capital Mobility in Developing Countries

WPS1212 The Links between Economic Policy and Research: Three Examples from Ghana and Some General Thoughts

WPS1213 Japanese Foreign Direct Investment: Kwang W. Jun Recent Trends, Determinants, and Prospects

WPS1214 Trade, Aid, and Investment in SubSaharan Africa

WPS1215 Hew Much Do Dstortions Affect Growth?

WPS1216 Regulation, Institutions, and Commitment: Privatization and

Regulation in the Argentine Telecommunications Sector

WPS1217 Unitary versus Collective Modeis of the Household. Time to Shift the Burden of Proof?

WPS1218 Implementation of Trade Reform in Sub-Saharan Africa: How Much Hea: and How Much Light?

WPS1219 Decentralizing Water Resource Management: Economic Incentives, Acrountability, and Assurance

WPS1220 Developing Countries and the Uruguay Round: Negotiations on Services

\section{Author}

Levi M Nyagura

Abby Riddell

Arvind Panagariya

Robin Boadway

Frank Flatters

Nlandu Mamingi

Ravi Kanbur

Frank Sader

Haruo Horaguchi

Hyuntai Kwak

Ishn at Husam

Willan Easterly

Alice till

Manuel Ange: Abdala

Pierre-Andre Chiappori

Lawence Haddad

John : Yodd nort

Ravi Kanbur

John Nash

K. William Easter

Robert R. Hearne

Bernard Hookman

\section{Date}

October 1993

Octuber 1993

October 1993

October 1993

Octcber 1993

Novernber 1993

S. King-Watson 33730

Novernber 1993

M. Youssef 34637

Novembe 1993

R. Martin 39065

Novmber 1993

D. Evans 38526

November 1993

P. Attipoo 526-3002

November 1993

D. Baliantyne 37947

November 1993

M. Wu

30480

November 1993
L. OConnor 37009 


\section{Pollcy Research Working Paper Serles}

Title

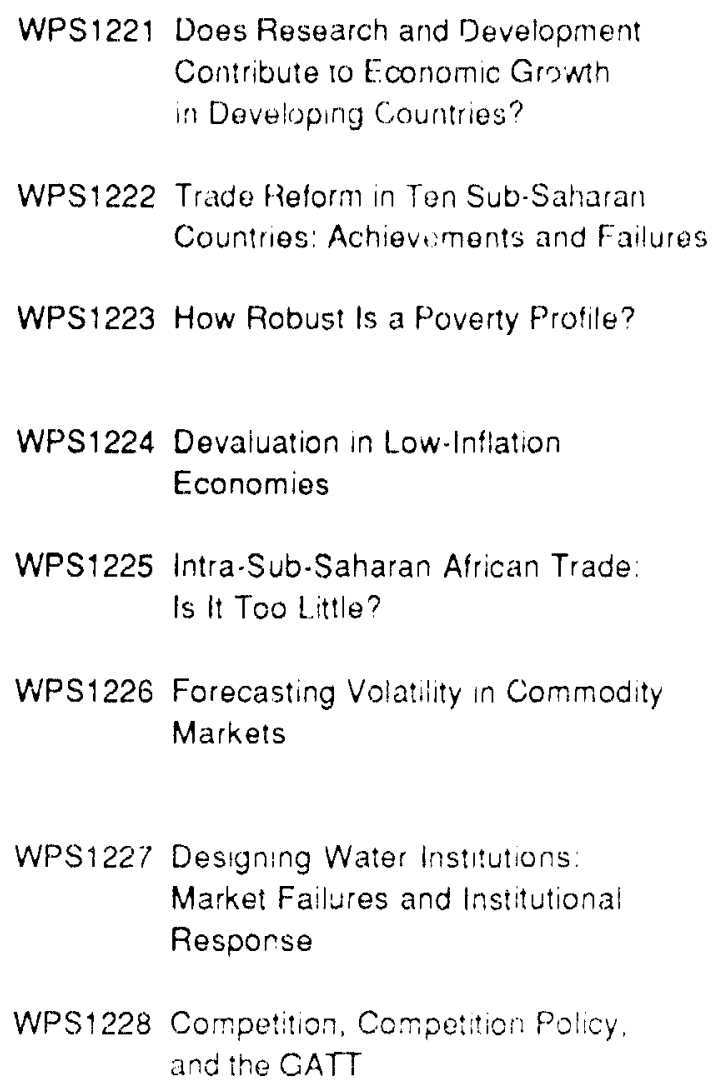

Author

Nancy Birdsall

Changyong Rhere

Fiezon Foroutan

Martin favallion

Benu Bidani

Miguel A Kiguel

Nita Ghei

Faezeh Foroutan

L.ant Pritchet:

Kenneth F. Kroner

Devin P. Kneatsey

Siin Claessens

Mare Leigh Livingston

Benard M Hoekman

Peios C. Mavroudis
December 1993

Contact

for paper

November 1993

S. Rajan 33747

November 1993

S. Fallon 38009

November 1993

P. Cook 33902

November 1993

R. Luz 39059

November 1993

S. Fallon 38009

November 1993 F. Hatab 35835

C. Spooner 30464

December 1993

1. O Connor 37009 